\title{
OSWAJANIE POPULIZMU. SCENA POLITYCZNA KRÓLESTWA NIDERLANDÓW PO 2015 ROKU
}

\section{Taming Populism: \\ The Political Scene of the Kingdom of the Netherlands after 2015}

The mass influx of immigrants to Europe in 2015 shook the foundations of the political system of the Kingdom of the Netherlands. The concept of populism dominated the political discourse related to various concepts of how to solve this problem. After the death of Pima Fortuyn and Theo van Gogh, two politicians using harsh anti-immigrant rhetoric and murdered by Islamic fanatics, a new generation of right-wing populist activists appeared on the political scene of the Kingdom of the Netherlands. Two of them, Geert Wilders and Thierry Baudet, run their own political parties and are increasingly successful. The Freedom Party of Geert Wilders became the second strongest party in the Kingdom of the Netherlands and the Forum for Democracy party founded by Thierry Baudet won two seats in the Second Chamber of Parliament in the 2017 election.

The author of this article focuses on both these politicians and their party programmes. He argues that the culmination of populism in Europe, which fell between the peak of the 2015 migration crisis and the 2017 parliamentary elections, has changed the attitude of leading politicians to this concept. Populism has been 'permanently' appearing in salons. The thesis of 'good' populism, proclaimed by Pim Minister Marek Rutte, indicates its inclusion in the arsenal of political means also used by liberals to defend a democratic order.

Keywords: populism, the Netherlands, Geert Wilders, Thierry Baudet, oikophobia, immigrants. 
Masowy napływ uchodźców do Europy w 2015 roku wstrząsnął podstawami systemu politycznego Królestwa Niderlandów. Dyskurs polityczny związany $z$ różnymi koncepcjami rozwiązania tego problemu zdominowało pojęcie populizmu, odmieniane przez wszystkie możliwe przypadki. Choć premier Mark Rutte ${ }^{1}$ i kierowana przez niego Partia Ludowa na rzecz Wolności i Demokracji wyszła zwycięsko z wyborów parlamentarnych w 2017 roku i polityk ten mógł ogłosić powstrzymanie w swoim kraju marszu populistów do władzy, walka ta daleka jest od zakończenia. Jak trafnie zauważył polski analityk sceny politycznej Niderlandów:

A że to w Holandii rodza się polityczne trendy, które później rozkwitaja w Europie, i to stamtad pochodzili dotychczasowi pionierzy europejskiego prawicowego populizmu, słychać wśród centrystów ostrzeżenia, że nadchodzi czas [Thierry'ego] Baudeta, który może się okazać groźniejszy niż [Geert] Wilders²

To celna uwaga. Aby zrozumieć drogę, która przebyły Niderlandy w tym krótkim czasie, warto obu wymienionym wyżej politykom przyjrzeć się nieco bliżej.

$\mathrm{Na}$ początek jednak trochę materiału empirycznego. Na łamach brytyjskiego dziennika „The Guardian” w listopadzie 2018 roku opublikowany został raport pod znamiennym tytułem: Jeden na czterech Europejczyków głosuje na populiste ${ }^{3} . \mathrm{Z}$ raportu tego wynika, że w ostatnich dwóch dekadach populiści potroili liczbę uzyskanych głosów, co pozwoliło im na umieszczenie swoich przedstawicieli na stanowiskach rządowych $\mathrm{w}$ jedenastu państwach i rzucenie wyzwania politycznemu porządkowi na całym kontynencie. Badania te zostały przeprowadzone na zamówienie redakcji dziennika, a baza ich były wyniki wyborów krajowych przeprowadzonych w ciagu dwóch dekad w trzydziestu jeden państwach europejskich. Do analizy zachodzacych zmian w Europie zaproszono ponad trzydziestu czołowych politologów $z$ całego świata. Wspomnianym projektem kierował Matthijs Rooduijn, socjolog-politolog pracujący na Wydziale Nauk Politycznych Uniwersytetu w Amsterdamie. Jest on badaczem młodego pokolenia. Stopień doktora w Amsterdamskim Instytucie Badań Nauk Społecz-

Mark Rutte (ur. 1967), niderlandzki polityk, parlamentarzysta, od 2006 lider Partii Ludowej na rzecz Wolności i Demokracji (nid. Volkspartij voor Vrijheid en Democratie, VVD), od 2010 premier Królestwa Niderlandów.

2 https://www.polityka.pl/tygodnikpolityka/swiat/1750110,2,holandia-thierry-baudet--czarujacy-populista.read

3 P. Lewis, S. Clarke, C.J. Holder, N. Kommenda, Revealed: one in four Europeans vote populist, https://www.theguardian.com/world/ng-interactive/2018/nov/20/revealed-one -in-four-europeans-vote-populist [dostęp: 6 marca 2019]. 
nych (Amsterdam Institute for Social Science Research, AISSR) uzyskał za rozprawę Populist Zeitgeist? The Impact of Populism on Parties, Media and the Public in Western Europe w 2013 roku' ${ }^{4}$ W pracy tej badał przyczyny i konsekwencje populizmu oraz radykalizmu społecznego. Naukowiec ten jest współzałożycielem, współredaktorem i stałym współpracownikiem niderlandzkiego bloga politologicznego o kontrowersyjnym tytule „Sztuka czerwonego mięsa” (nid. Stuk Rood Vlees) i bloga na temat polityki europejskiej (EUROPP) przy London School of Economics. Rooduijn jest także autorem licznych publikacji na łamach niderlandzkojęzycznej prasy różnych odcieni, od „NRC Handelsblad”, przez „De Volkskrant”, „Trouw” do „De Groene Amsterdammer”, a także angielskojęzycznych dzienników „The Guardian”, „Washington Post” oraz „Newsweek”.

Dane przedstawione przez Rooduijna w cytowanym raporcie pokazuja, że populizm wykazuje tendencję wzrostową od co najmniej 1998 roku.

Początkowo partie populistyczne były w dużej mierze siłą marginalną i stanowiły zaledwie 7 procent głosów na całym kontynencie. W ostatnich wyborach na szczeblach jeden na cztery głosy oddany został już na partię populistyczną ${ }^{6}$.

W wyniku kryzysu uchodźczego w 2015 roku na dobre zagościł w najważniejszych państwach Europy Zachodniej . Populiści w Europie pojawili się w całym spektrum politycznym, od lewicy po prawicę ${ }^{8}$.

Dalsza część tego teksu zostanie poświęcona omówieniu, jak na tym tle wygląda Królestwo Niderlandów.

\section{POPULIZM W KRÓLESTWIE NIDERLANDÓW}

Temat populizmu w Królestwie Niderlandów cieszył się i nadal cieszy zainteresowaniem polskich mediów i komentatorów politycznych, głównie ze względu na spektakularne działania dwóch polityków Pima Fortuyna i Geerta Wildersa, obu charakteryzujących się ostra, antyimigrancka retoryka. Temu pierwszemu, tragicznie zamordowanemu w 2002 roku politykowi poświęcone zostało kilka publikacji naukowych w języku polskim, głównie autorstwa Aleksandry Moroski-

\footnotetext{
http://matthijsrooduijn.nl/ [dostęp: 6 marca 2019].

Ibidem.

P. Lewis, S. Clarke, C.J. Holder, N. Kommenda. Revealed: one in four ...

Metodologia badań zob.: https://www.theguardian.com/world/2018/nov/20/measuring-populism-how-guardian-charted-rise-methodology [dostęp: 6 marca 2019].

8 Ibidem.
} 
-Bonkiewicz, autorki doktoratu i monografii na temat eurosceptyzmu w wersji Fortuyna ${ }^{9}$, a także publikacji w „Krakowskich Studiach Międzynarodowych", których zeszyt zatytułowany Populizm wyzwaniem dla dobrego rzadzenia $i$ wspólpracy międzynarodowej poświęcony został $\mathrm{w}$ całości tej tematyce ${ }^{10}$. Zainteresowanych tym okresem odsyłam do przywołanych prac. Zawieraja one obszerna bibliografię na temat teorii populizmu oraz analizę sytuacji wewnętrznej w okresie działalności Pima Fortuyna ${ }^{11} \mathrm{i}$ Theo van Gogha ${ }^{12}$, kontrowersyjnych osobowości o radykalnych na owe czasy poglądach, za które zapłacili najwyższą cenę.

Życie polityczne nie znosi próżni. Od tego czasu na scenie politycznej pojawiło się nowe pokolenie polityków, którzy w niemniej spektakularny sposób ogniskuja uwagę opinii publicznej. Poniżej uwagę poświęcę dwóm $z$ nich i poddam analizie ich program oraz wpływ na kształt populizmu w Królestwie Niderlandów. Za punkt wyjścia przyjmuję rok 2015, kiedy to w związu $z$ kryzysem imigracyjnym populizm w Europie osiagnał maksymalne natężenie. Na fali tej karierę medialną zrobili politycy o wyraźnych, kontrowersyjnych osobowościach, a rola ich $\mathrm{w}$ polityce wewnętrznej ulega wzmocnieniu. W przypadku Królestwa Niderlandów mam na myśli dwóch - obu o charyzmatycznych osobowościach - Geerta Wildersa, znanego opinii publicznej polityka o dwudziestoletnim stażu i Thierry'ego Baudeta, eurosceptyka, nowa gwiazdę sceny politycznej tego państwa. Poniżej przeanalizuję ich poglądy i kariery polityczne.

\section{GEERT WILDERS}

Geert Wilders urodził się w rodzinie katolickiej 6 września 1963 roku w prowincji Limburgia, w mieście Venlo, na pograniczu nider-

\footnotetext{
9 A. Moroska, Prawicowy populizm a eurosceptycyzm (na przykładzie Listy Pima Fortuyna $w$ Holandii i Ligi Polskich Rodzin $w$ Polsce), Wydawnictwo Uniwersytetu Wrocławskiego, Wrocław 2010. Przychylam się do definicji prawicowego populizmu przedstawionej przez tę autorkę.

10 A. Moroska-Bonkiewicz, Prawicowy populizm $w$ Holandii - Lista Pima Fortuyna i Partia na rzecz Wolności. Kontynuacja czy zmiana? w: Populizm wyzwaniem dla dobrego rzadzenia i wspótpracy międzynarodowej, red. E. Cziomer, „Krakowskie Studia Międzynarodowe” 2011, nr 4 (VIII), „Populizm europejski”, s. 133-152.

11 Wilhelmus Simon Petrus „Pim” Fortuyn (1948-2002), polityk niderlandzki, profesor socjologii, przewodniczacy założonej przez siebie populistycznej Listy Pima Fortuyna. Został zastrzelony przez aktywistę na rzecz praw zwierząt w czasie kampanii wyborczej do Drugiej Izby Parlamentu w 2002 roku.

12 Theo van Gogh (1957-2004), niderlandzki reżyser, publicysta i aktor, znany z krytyki świata islamskiego, $z$ rodziny malarza Vincenta; prawnuk Theo van Gogha, handlarza dziełami sztuki. Zamordowany został 2 listopada 2004 roku w Amsterdamie, gdy jechał rowerem do pracy, przez 26-letniego syna marokańskiego imigranta.
} 
landzko-niemieckim. Ze wspólnoty religijnej wystapił w wieku pełnoletnim i obecnie światopoglądowo definiuje siebie jako agnostyka. Szkołę średnią ukończył w miejscu urodzenia, na dalszą naukę udał się do Amsterdamu, gdzie zdobywał wiedzę w zakresie ubezpieczeń społecznych. W wieku 18 lat rozpoczą pierwsza pracę w niemieckiej fabryce ogórków. Gdy jego młoda przyjaciółka wraz z rodziną wyjechała do Izraela, postanowił ja odwiedzić. Lata 1980-1982 spędził w moszawie (kibucu) w Izraelu, gdzie poznawał kraj i kulturę Żydów, a w miejscowej piekarni zarabiał pieniądze, za które odbył podróż po państwach arabskich. W wywiadzie dla dziennika „Volkskrant” o tych latach opowiadał tak:

Już w 1982 roku, jako 18-latek, zauważyłem nienawiść między tymi państwami i brutalne represje ze strony niedemokratycznych przywódców. W Egipcie spontanicznie zaprosiłem na herbatę bardzo przyjazną egipską rodzinę, ale gdy tylko padło słowo Izrael - nazwa kraju, z którym Egipt już formalnie zawarł pokój - w ich oczach i obecnej większości innych czaiła się czysta nienawiść ${ }^{13}$.

Podróż ta pozostawiła niezatarte wrażenie na młodym Wilderze. Jego miłość do Izraela, „jedynej demokracji na całym Bliskim Wschodzie", nigdy nie utraciła swej intensywności. W państwie żydowskim bywał często.

W ostatnich latach odwiedziłem wiele interesujących krajów w tym regionie: od Syrii po Egipt, od Tunezji po Turcję i od Cypru po Iran. Ale nigdzie nie mam tego szczególnego uczucia przynależności, które ogarnia mnie, gdy stawiam nogę na izraelskiej ziemi na lotnisku Ben Gurion.

Tak mówił Wilders w przemówieniu wyborczym w Tel Awiwie w 2003 roku $^{14}$. Po powrocie do Niderlandów dokształcał się na Open University. Przez kilka kolejnych lat pracował w firmach ubezpieczeniowych Ziekenfondsraad i Sociale Verzekeringsraad.

Geert Wilders od 25 sierpnia 1998 do 23 maja 2002 roku był członkiem Drugiej Izby Parlamentu $z$ ramienia VVD. Funkcję tę pełnił do 2 września 2004 roku, kiedy to zdecydował się na utworzenie jednoosobowej frakcji parlamentarnej w Parlamencie (nid. Tweede Kamerfractie Groep-Wilders). Wraz z kolega partyjnym Gertem-Janem Oplaatem ${ }^{15}$

13 https://www.volkskrant.nl/nieuws-achtergrond/verliefd-op-israel b7a61ce5/?referer=https://nl.wikipedia.org/ [dostęp: 6 marca 2019].

14 Ibidem.

15 Gert-Jan Oplaat (ur. 1964), niderlandzki polityk, w latach 1998-2006 był członkiem Drugiej Izby Parlamentu, 2006-2014 przewodniczącym VVD w prowincji Overijssel. 
napisali dziesięciopunktowy „wewnętrzny manifest”, w którym wezwali kierownictwo VVD do poprowadzenia partii w kierunku bardziej prawicowym. Wilders wdał się w spór polityczny $z$ ówczesnym jej liderem Joziasem van Aartsenem ${ }^{16}$, sprzeciwiając się ostro przyjęciu Turcji do Unii Europejskiej. Wilders i Oplaat postulowali między innymi wydalenie $z$ kraju radykalnych muzułmanów, opowiedzieli się za zasada three strikes and you're out (trzy uderzenia i jesteś wykluczony), w wyniku której przestępcy po trzech prawomocnych wyrokach sadowych powinni otrzymać karę dożywocia. Postulowali także zmniejszenie wydatków na rozwój współpracy $z$ państwami trzeciego świata (nid. Ontwikkelingssamenwerking) a także ... podwyższenie prędkości na drogach Królestwa Niderlandów. W dniu 2 września 2004 roku nastapiło ostateczne zerwanie więzi pomiędzy Wildersem a partia, choć nie zrezygnował on $z$ uzyskanego miejsca w Parlamencie. Działalność polityczna postanowił kontynuować w postaci jednoosobowej frakcji Grupa Wilders.

W 2005 roku polityk ten postanowił pójść o krok dalej i utworzył ugrupowanie pod nazwą Partia Wolności (nid. Partij voor de Vrijheid, PVV), co uroczyście zostało ogłoszone w tzw. deklaracji niepodległości (nid. onafhankelijkheidsverklaring) ${ }^{17}$. Pierwsza, zakończona sukcesem kampania Wildersa było odrzucenie konstytucji europejskiej w referendum w 2005 roku, druga zaś było uzyskanie rok później w wyborach do Parlamentu dziewięciu miejsc dla swojej partii. Głównym celem jego kampanii był muzułmański ekstremizm, który swą zbrodnicza naturę objawił $\mathrm{w}$ zamachach przeprowadzonych w Stanach Zjednoczonych 11 września 2001 roku. Wilders piętnował ekstremizm oraz sam islam zarówno w Parlamencie, jak i we wszystkich wystapieniach publicznych. Stopniowo jego poglądy stawały się coraz bardziej radykalne. Ponieważ w debacie publicznej przestano czynić rozróżnienie między ekstremizmem a islamem, wyznanie to stało się dla niego totalitarna ideologią. Zaczął porównywać Koran z Mein Kampf, żądajac zakazu propagowania także tego pierwszego. Zaproponował wprowadzenie podatku od noszenia chust, postulował deportację milionów muzułmanów $z$ Europy oraz wystapienie państwa zarówno ze strefy euro, jak i $z$ Unii Europejskiej.

16 Jozias Johannes van Aartsen (ur. 1947), niderlandzki polityk i urzędnik państwowy, w latach 2006-2008 lider VVD, 1994-1998 minister rolnictwa, 1998-2002 minister spraw zagranicznych, 2008-2017 burmistrz Hagi.

17 https://www.pvv.nl/index.php/component/content/article/30-publicaties/684-onafhankelijkheidsverklaring [dostęp: 6 marca 2019]. 
W kolejnych wyborach parlamentarnych w 2010 roku PVV zdobyła 24 mandaty, zaś w wyniku wyborów w 2017 roku partia ta stała się druga największą siłą polityczną Królestwa Niderlandów.

\section{TABELA}

Wyniki wyborów w latach 2012 i 2017

\begin{tabular}{|l|c|c|c|c|c|c|c|c|}
\hline Partie & $\begin{array}{c}\text { Liczba } \\
\text { oddanych } \\
\text { głosów } \\
2012\end{array}$ & $\%$ & $\begin{array}{c}\text { Liczba } \\
\text { mandatów }\end{array}$ & $\begin{array}{c}\text { Liczba } \\
\text { oddanych } \\
\text { głosów } \\
2017\end{array}$ & $\%$ & $\begin{array}{c}\text { Liczba } \\
\text { mandatów }\end{array}$ & $\begin{array}{c}\text { Dynamika } \\
\text { zmian } \\
\%\end{array}$ & $\begin{array}{c}\text { Dynamika } \\
\text { zmian } \\
\text { mandaty }\end{array}$ \\
\hline VVD & 2504948 & 26,58 & 41 & 2238351 & 21,29 & 33 & $-5,29$ & -8 \\
PVV & 950263 & 10,08 & 15 & 1372941 & 13,06 & 20 & $+2,98$ & +5 \\
CDA & 801620 & 8,51 & 13 & 1301796 & 12,38 & 19 & $+3,87$ & +6 \\
\hline
\end{tabular}

Źródło: Opracowanie własne.

Redakcja popularnego programu telewizyjnego „EenVandaag” w Hadze od 2003 roku ogłasza plebiscyt na polityka roku. W latach 2010, 2013, 2015 i 2016 w głosowaniach tych zwyciężał Geert Wilders. W 2018 roku w piętnastej edycji plebiscytu na Polityka Roku pierwsze miejsce, co prawda, zają przewodniczacy frakcji parlamentarnej VVD Klaas Dijkhoff ${ }^{18}$, ale na drugim miejscu kolejny raz znalazł się Geert Wilders.

Co czyni go tak atrakcyjnym w oczach niderlandzkich telewidzów? Wilders jest szczególnie chwalony przez respondentów za jego działania w związku z kryzysem uchodźczym. „Jako jedyny polityk zwraca uwagę na obawy, które wielu Holendrów wyraża na temat osób ubiegających się o azyl” - pisał w uzasadnieniu swojego wyboru jeden z uczestników plebiscytu ${ }^{19}$. Inny zaś dodawał: „Choć jest odrzucany przez wszystkich i uznawany za rasistę, w międzyczasie wiele $z$ jego zapowiedzi jednak się spełniło” ${ }^{20}$. Widzowie „EenVandaag” uważaja, że Wilders jest politykiem, który uważnie słucha głosu ludu.

$18 \mathrm{https}$ ///eenvandaag.avrotros.nl/panels/opiniepanel/alle-uitslagen/item/klaasdijkhoff-gekozen-tot-politicus-van-het-jaar-2018/ [dostęp: 6 marca 2019]; Klaas Henricus Dominicus Maria Dijkhoff (ur. 1981), polityk niderlandzki, od 23 marca członek Drugiej Izby Parlamentu, a od 26 października 2017 roku przewodniczący frakcji parlamentarnej VVD. W gabinecie Rutte II w latach 2015-2017 był sekretarzem stanu ds. bezpieczeństwa i sprawiedliwości, a w 2017 roku ministrem obrony, https://www.tweedekamer.nl/kamerleden_en_commissies/alle_kamerleden/dijkhoff-khdm-vvd [dostęp: 6 marca 2019].

${ }_{19}$ https://eenvandaag.avrotros.nl/item/wilders-politicus-van-het-jaar-2015/ [dostęp: 6 marca 2019].

20 Ibidem. 


\section{„ICH EUROPA, NASZE NIDERLANDY". PROGRAM PVV NA LATA 2017-2021}

Program wyborczy PVV na lata 2017-2021 został opublikowany przez Geerta Wildersa na stronie internetowej partii ${ }^{21}$ oraz na Facebooku i Twitterze. Ma on objętość pojedynczego arkusza papieru formatu A4 i składa się z jedenastu punktów:

- Deislamizacja Niderlandów (Holandii); zero miejsca dla poszukujących azylu, żadnych kolejnych imigrantów $z$ krajów muzułmańskich: zamknięcie granic, unieważnienie wszystkich udzielonych czasowo zezwoleń na pobyt; likwidacja Centrów Przyjmowania Imigrantów (AZC); zakaz noszenia chust w miejscach publicznych; zakaz propagowania islamu, który jest sprzeczny $z$ porządkiem publicznym; prewencyjne areszty dla radykalnych muzułmanów; pozbawienie obywatelstwa i wydalenie $z$ kraju przestępców o podwójnym obywatelstwie; odmowa zgody na powrót ochotników $z$ wojny w Syrii; zamknięcie wszystkich meczetów i szkół islamskich oraz zakaz głoszenia Koranu.

- Niderlandy ponownie niezależne. Także od Unii Europejskiej.

- Demokracja bezpośrednia; wprowadzenie wiążącego referendum; władza dla obywateli.

- Całkowita likwidacja ochrony zdrowia w trybie tzw. własnego ryzyka.

- Obniżenie kosztów wynajmu mieszkań.

- Wiek emerytalny na poziomie 65 lat; pełna indeksacja emerytur.

- Koniec $z$ wydatkami na pomoc rozwojowa, na wiatraki, sztuke i innowacyjność, na organizacje radiowe i telewizyjne itd.

- Wycofanie się $z$ cięć wydatków na opiekę domowa; na opiekę nad osobami starszymi, więcej rąk do opieki przy łóżku.

- Zwiększenie nakładów finansowych na obronę i policję.

- Obniżenie podatku dochodowego.

- Zmniejszenie podatku od pojazdów silnikowych ${ }^{22}$.

W najkrótszej ocenie programu rzuca się w oczy, że jest on bardziej radykalny niż ten z 2012 roku. PVV chce ograniczyć liczbę osób ubiegających się o azyl do maksymalnie tysiąca osób rocznie. Zapowiada wyjście $z$ Unii Europejskiej (Nexit), chce także całkowicie zlikwidować udział własny w sektorze opieki oraz obniżyć wiek emerytalny do 65 lat.

${ }^{21}$ https://www.pvv.nl/visie.html [dostęp: 6 marca 2019]. 2019].

22 https://www.pvv.nl/images/Conceptverkiezingsprogrammma.pdf [dostęp: 6 marca 
Za zaletę programu uznano jego zwięzłość. Większość ludzi nie lubi czytać obszernych dokumentów programowych, stąd też ze względu na jego zwięzłą formę trafił on do wielu. W ocenie mediów niderlandzkich tak zarysowany program partii w wielu kwestiach jest jednak sprzeczny z Konstytucja i konwencjami dotyczacymi praw człowieka. Na przykład, prawo do azylu jest określone w art. 18 konwencji genewskiej. Rząd Niderlandów nie może zatem usunąć wszystkich osób ubiegajacych się o azyl bez naruszenia tej konwencji. W Konstytucji zapisana jest wolność słowa i wolność wyznania (art. 6 i 7). Zakaz funkcjonowania meczetów i zakaz głoszenia Koranu sa sprzeczne $z$ tymi podstawowymi wolnościami ${ }^{23}$.

\section{THIERRY BAUDET}

Thierry Henri Philippe Baudet urodził się 28 stycznia 1983 roku w miasteczku Heemstede w prowincji Północna Holandia. W latach 2001-2006 studiował historię na Uniwersytecie Amsterdamskim. W roku 2012 doktoryzował się na wydziale prawa Uniwersytetu w Lejdzie. Pracował jako nauczyciel akademicki na tej uczelni oraz na Uniwersytecie w Tilburgu. Zajął się również działalnościa publicystyczna i komentatorską. Był założycielem i dyrektorem Pop-up University, struktury pomagającej absolwentom szkół średnich w znalezieniu dogodnej dla siebie oferty studiów ${ }^{24}$ oraz przewodniczącym think-tanku Forum na rzecz Demokracji ${ }^{25}$, na bazie którego powołał następnie partię polityczna.

Na początku 2013 roku Baudet, wspierany przez ósemkę pracowników akademickich, wezwał do przeprowadzenia referendum w sprawie przyszłości Niderlandów w Unii Europejskiej26. W dniu 26 marca 2013 roku inicjatorzy akcji przedstawili Drugiej Izbie Parlamentu ponad pięćdziesiąt sześć tysięcy podpisów, przekraczając limit czterdziestu tysięcy sygnatariuszy, czyniąc $z$ petycji tej punkt programu w Parlamencie $^{27}$. W dniu 21 stycznia 2014 roku przedłożona inicjatywa

${ }^{23}$ https://mens-en-samenleving.infonu.nl/politiek/ 175562-het-verkiezingsprogramma-van-de-pvv-voor-2017-2021.html [dostęp: 6 marca 2019].

${ }^{24}$ https://www.utwente.nl/nl/popupuniversity/ [dostęp: 6 marca 2019].

25 https://web.archive.org/web/20170302030218/https://www.parlement.com/id/ vjuuhtscjwpn/t_h_ph_thierry_baudet [dostęp: 6 marca 2019].

${ }^{26}$ Pim van Dool, Onherroepelijk richting een federale unie. Ook wij eisen een referendum!, „NRC Handelsblad”, 26 januari 2013, https://www.nrc.nl/nieuws/2013/01/26/ ook-wij-eisen-een-referendum-a1437834 [dostęp: 6 marca 2019].

27 Burgerinitiatief EU-referendum in Kamer, tweedekamer.nl, 22 januari 2014, https:// www.tweedekamer.nl/nieuws/kamernieuws/newspage2480_burgerinitiatief_eu_referendum 
obywatelska została omówiona w Drugiej Izbie ${ }^{28}$, jednakże nie uzyskała ona większości i sprawa referendum została odłożona ad acta ${ }^{29}$.

Aby rozpowszechniać swoje idee eurosceptyczne Thierry Baudet w 2015 roku założył wspomniany niezależny think-tank Forum na rzecz Demokracji.

Baudet stał się znany jako jeden $z$ inicjatorów GeenPeil, który w 2016 roku prowadził aktywną kampanię na „nie” przed referendum dotyczącym układu stowarzyszeniowego między Unią Europejska a Ukraina ${ }^{30}$. W referendum większość społeczeństwa opowiedziała się przeciwko traktatowi ${ }^{31}$. W wywiadzie udzielonym Jędrzejowi Bieleckiemu dla „Rzeczpospolitej” Thierry Baudet mówił tak:

Pytanie: Jak wpadł pan na pomysł referendum?

Jestem dyrektorem think tanku Forum na rzecz Demokracji. Przez trzy lata lobbowaliśmy na rzecz ustawy, która umożliwi rozpisanie referendum $z$ inicjatywy społecznej. Gdy to się udało, w czerwcu 2015 roku rozpoczęliśmy szukanie projektu, który pokaże fatalne działania Unii. I pojawił się neokonserwatywny, jastrzębi pomysł Radosława Sikorskiego poszerzenia UE i NATO tak daleko, jak można - układ z Ukraina. 6 kwietnia 61 proc. Holendrów go odrzuciło $^{32}$.

Forum na rzecz Demokracji wzięło udział w wyborach parlamentarnych 15 marca 2017 roku i zdobyło dwa mandaty. Objęli je Theo Hiddema $^{33}$ i Thierry Baudet. Od 23 marca 2017 roku Baudet jest przewodniczacym frakcji parlamentarnej Forum.

Sukcesy jej przewodniczącego przykuły uwage polskiego publicysty. Jędrzej Winiecki, na łamach tygodnika „Polityka” w 2018 roku opublikował artykuł pod znamiennym tytułem: Holandia: Thierry Baudet-czarujacy populista. Dandys $z$ brzytwa.

28 Joost de Vries, EU-burgerforum bepaalt voor even de agenda van de Kamer, „de Volkskrant", 21 januari 2014, https://www.volkskrant.nl/nieuws-achtergrond/eu-burgerforum -bepaalt-voor-even-de-agenda-van-de-kamer b41ed 1a1/?referer=https\%3A\%2F\%2Fwww. google.com\%2F [dostęp: 6 marca 2019].

${ }^{29}$ Geen meerderheid voor Europees referendum, tweedekamer.nl, 21 januari 2014.

30 https://www.parlement.com/id/vjuuhtscjwpn/t_h_ph_thierry_baudet [dostęp: 6 marca 2019].

31 Wynik: 61 proc. głosów przeciw (2 509395 wyborców), 38,21 proc. za (1 571874 wyborców). Uitslag referendum Associatieovereenkomst met Oekraïne Kiesraad, 12 april 2016, https://www.kiesraad.nl/actueel/nieuws/2016/04/12/uitslag-referendum-associatieovereenkomst-met-oekrainehttps://www.kiesraad.nl/actueel/nieuws/2016/04/12/uitslag-referendum-associatieovereenkomst-met-oekraine [dostęp: 6 marca 2019].

32 J. Bielecki, „Rzeczpospolita” 25 września 2016, https://www.rp.pl/Unia-Europejska/309259952-Holandia-dobija-Majdan---rozmowa-z-Thierrym-Baudetem.html [dostęp: 6 marca 2019].

33 Theo Upt Hiddema (ur. 1944), prawnik, specjalista od mediów i członek Forum na rzecz Demokracji. 
Holender Thierry Baudet to nowe wcielenie prawicowego populizmu w Europie. Młodsza, gładsza - i bardziej niebezpieczna wersja Geerta Wildersa. „Ekstremalne pomysły w czarującym opakowaniu” - piszą o nim holenderscy komentatorzy. Pozuje na dandysa, nosi się elegancko. Sprowadził z domu do parlamentu gabinetowy fortepian. Jest mu potrzebny do relaksu, w przerwach obrad grywa Brahmsa, Schuberta i Bacha. Dopiero co skończył 35 lat, a zdążył napisać kilka książek, w tym m.in. rozprawę doktorską i dwie powieści. Dorobek literacki i klasyczne wykształcenie (łacina i greka w liceum, prawo, historia i filozofia na uniwersytecie) pozwalają mu staroświeckość uzupełnić o rys myśliciela. Jak mówi, jest przecież najważniejszym intelektualista w Holandii ${ }^{34}$.

Warto zatem bliżej poznać strukturę Forum i wartości, które partia ta promuje w społeczeństwie Niderlandów.

\section{FORUM NA RZECZ DEMOKRACJI}

Na stronie internetowej działacze Forum na rzecz Demokracji (dalej FvD) chwalą się popularnością. „W ciagu roku mamy już ponad połowę członków, których tradycyjne partie budowały od wielu dziesięcioleci" - pisza ${ }^{35}$. Ich liczbę określają na około 31 tysięcy. Na program FvD składaja się cztery filary: stosunek do Unii Europejskiej, stosunek do imigracji ${ }^{36}$ i emigracji, opieka zdrowotna, demokracja bezpośrednia i „sanacja” mediów, zwłaszcza NPO (Nederlandse Publieke Omroep - sieć publicznych towarzystw radiowych i telewizyjnych działających w tym państwie).

Postulaty FvD względem Unii Europejskiej sprowadzają się do przeprowadzenia trzech referendów:

- w sprawie kontynuacji członkostwa Niderlandów w strefie euro;

- w sprawie kontynuacji otwartych granic i swobodnego, niekontrolowanego przepływu osób w Unii Europejskiej;

- w sprawie członkostwa Niderlandów w Unii Europejskiej.

Stosunek swój do UE określaja tak: „Europa”, europejska cywilizacja i europejska współpraca są bardzo ważne, także dla Forum na rzecz Demokracji. Właśnie dlatego jesteśmy przeciwko UE" ${ }^{37}$. W uzasadnieniu swojej negatywnej oceny tej struktury autorzy programu

${ }^{34}$ J. Winiecki, Holandia: Thierry Baudet - czarujacy populista, „Polityka”, 28 maja 2018, https://www.polityka.pl/tygodnikpolityka/swiat/1750110,2, holandia-thierry-baudet--czarujacy-populista.read

35 https://forumvoordemocratie.nl/ [dostęp: 6 marca 2019].

36 Interesujace jest, że zarówno G. Wilders, jak i Th. Baudet unikają określenia uchodźca (nid. vluchteling) i azylant (nid. azielzoeker), zamiast tego $\mathrm{w}$ dokumentach pojawia się niejasna kategoria imigrant (nid. immigrant).

37 https://forumvoordemocratie.nl/ [dostęp: 6 marca 2019]. 
dodaja, że Unia Europejska została zbyt mocno rozszerzona i zamieniła się w całkowicie niedemokratycznego molocha. Jest to, w ich ocenie, wynik posługiwania się przestarzałym modelem zarządzania. $\mathrm{W}$ rezultacie stała się ona pionową strukturą władzy, składającą się z karteli („kartel na kartelu”). FvD uważa, że UE jest niereformowalna i dlatego opowiada się za referendum w sprawie Nexit (wyjścia z Unii Europejskiej).

Ostro krytykują euro. Uważają, że sposób, w jaki jest ono podtrzymywane „przy życiu”, jest skandaliczny i że kosztuje Niderlandy coraz więcej miliardów $z$ państwowej kasy, a jednocześnie niszczy gospodarki Europy Południowej. Autorzy programu Forum piszą:

Otwarte granice prowadza do niekontrolowanej imigracji i większego ryzyka ataków terrorystycznych, a polityka zagraniczna UE wielokrotnie „wrzucała nas" w lekkomyślne awanturnictwo (takie jak dramatyczna umowa stowarzyszeniowa $z$ Ukraina, która wywołała wojnę domową i konflikt $z$ Rosja). Nadszedł czas, aby zatrzymać unię walutową i otwarte granice, a następnie opuścić UE. Chcemy współpracować i handlować - a jest to możliwe dzięki Europejskiemu Stowarzyszeniu Wolnego Handlu i dzięki członkostwu w Europejskim Obszarze Gospodarczym oraz oczywiście wielu innym międzynarodowym konwencjom. Ale UE otwartych granic i euro musimy się pozbyćc ${ }^{38}$.

\section{IMIGRACJA}

Wobec polityki imigracyjnej państwa Forum na rzecz Demokracji stawia osiem postulatów.

- Polityka azylowa Niderlandów powinna wzorować się na australijskim modelu: państwo ma samo decydować o tym, kto ma być objęty opieką azylową. Imigranci o skrajnych poglądach politycznych, które nie sa zgodne ze standardami Cywilizacji Zachodniej, powinni być natychmiast deportowani do kraju pochodzenia.

- Fundusze publiczne będa wydawane znacznie lepiej i skuteczniej na opiekę w regionie pochodzenia imigrantów.

- Wniosek o azyl nie powinien prowadzić do automatycznego zezwolenia na pobyt stały, ale (co najwyżej) do tymczasowej opieki państwa przyjmującego. Celem nadrzędnym musi być powrót imigrantów do kraju ich pochodzenia.

- Pożądane jest wprowadzenie systemu GreenCard [zielonej karty] wzorowanego na amerykańskim modelu dla czasowych imigrantów za praca.

38 Ibidem. 
- Należy prowadzić aktywna politykę wydalania nielegalnych imigrantów; penalizować nielegalność.

- Posiadacze podwójnych paszportów traca holenderski paszport, gdy popełnia (poważne) przestępstwa.

- Należy popierać reemigrację tam, gdzie zawodzi integracja (asymilacja).

- Wprowadzić ograniczenie odwołania od decyzji w sprawach azylowych do jednego organu.

Działacze FvD dostrzegaja, że niderlandzkie społeczeństwo może już sobie poradzić $z$ napływem imigrantów, ale partyjny kartel będzie nadal ich ściagał do kraju przy wsparciu organizacji non-profit i instytucji subsydiowanych, takich jak na przykład Refugee Work. Pieniądze wydawane na pomoc imigrantom mogłyby zostać bardziej efektywnie wydane na pomoc $\mathrm{w}$ regionie, $\mathrm{z}$ którego pochodzą. Jeżeli azyl w Niderlandach jest $z$ jakiś powodów konieczny, nie powinien on oznaczać uzyskania zezwolenia na pobyt stały, lecz sprowadzać się jedynie do tymczasowej opieki. Celem państwa powinna być pomoc w powrocie imigranta do kraju pochodzenia, gdy tylko pozwoli na to sytuacja.

\section{DEMOKRACJA BEZPOŚREDNIA}

W odniesieniu do tego ważnego elementu ustrojowego FvD stawia trzy postulaty:

- Wprowadzenie wiążacych referendów w ramach oddolnych inicjatyw według szwajcarskiego modelu, aby przełamać partyjny kartel i poważnie zwiększyć wpływ wyborców na życie polityczne państwa.

- Wybór burmistrzów we wszystkich gminach Niderlandów począwszy od 1 stycznia 2018 roku [obecnie sa oni mianowani przez monarchę]. Każdy obywatel państwa musi mieć prawo do kandydowania w wyborach na burmistrza.

- Zmniejszenie i polepszenie jakości administracji publicznej.

FvD proponujac wprowadzenie wiążących referendów wzorowanych na szwajcarskim modelu. Zmusi to polityków, zdaniem działaczy FvD, do utrzymywania większego kontaktu $z$ obywatelami. Dla wzmocnienia demokracji bezpośredniej FvD uruchomiło aplikacje internetowa, pod nazwa „Pulpit [Dasboard] Demokracji”, za pomoca której niderlandzcy wyborcy moga inicjować oraz wspierać kampanie online, petycje i crowdfunding, a także aplikować o funkcje publiczne. 


\section{NOWOCZESNE MEDIA W POLITYCE}

Zgodnie $z$ duchem czasu Baudet ${ }^{39}$ posługuje się cała gamą mediów społecznościowych. Czasopismo „Diggit Magazine” wzięło pod lupe Forum na rzecz Demokracji i przeanalizowało, w jaki sposób Baudet korzysta $z$ prawa do wolności słowa przy propagowaniu nacjonalizmu za pomoca różnych platform mediów społecznościowych ${ }^{40}$. Konto FvD na Facebooku ma 129 tysięcy obserwatorów, a liczba ich wciąż rośnie. Jak piszą redaktorzy „Diggit Magazine”:

Posty FdD sa czysto polityczne, a administratorzy strony sa bardzo interaktywni w stosunku do swoich odbiorców, wykorzystując różne media do komunikowania się ze swoimi obserwatorami za pomoca takich środków, jak filmy wideo, wywiady czy zdjęcia członków parlamentu [z komentarzem]. Intencje twórców postów widoczne są wyraźnie w sposobie poruszania tematów, które często dotyczą napływu imigrantów, a odsyłajac do artykułów powiązanych ze stroną internetowa, zachęcają użytkowników do głosowania, wsparcia lub dołaczenia do zespołu FVD ${ }^{41}$.

Partia jest przeciwna integracji kultury islamskiej ze społeczeństwem w obawie przed zagrożeniem niderlandzkiej tożsamości $(\mathrm{z}$ tychże samych powodów odrzucają Unię Europejska).

Popularnym narzędziem komunikacji używanym przez Forum sa filmy wideo, w których Baudet bezpośrednio zwraca się do śledzących jego posty na Facebooku, zwłaszcza do najmłodszego pokolenia. Na platformach społecznościowych, FvD z 74,3 tysiacami obserwatorów na Twitterze i 16,6 tysiącami na Instagramie, głos Baudeta i Forum jest słyszalny w całych Niderlandach. Twitter jest też głównym nośnikiem informacji i promocji partii oraz instrumentem przekazywaniem opinii polityka na temat Niderlandów i Unii Europejskiej.

Instagram Baudeta ma nieco inny charakter i ma ocieplać jego wizerunek. Ukazują się na nim przemiennie treści publiczne i prywatne, pozwalając nam, jako osobom z zewnątrz, przyjrzeć się bliżej jego życiu. Baudet publikuje modne memy i selfie. Baudet śmieje się, żartuje i nosi codzienne ubrania, takie jak dżinsy i t-shirty, pokazując, że jest „normalnym” facetem ${ }^{42}$. Przy okazji jednak prezentuje swoje poglądy

39 Oprócz przewodniczenia frakcji partyjnej w Parlamencie Baudet jest między innymi rzecznikiem spraw zagranicznych, spraw europejskich, finansów, gospodarki, edukacji, zdrowia publicznego i infrastruktury oraz środowiska, https://www.parlement.com/id/ vjuuhtscjwpn/t_h_ph_thierry_baudet [dostęp: 6 marca 2019].

40 https://www.diggitmagazine.com/articles/politics-and-digital-media-thierry-baudet-and-forum-voor-democratie [dostęp: 6 marca 2019].

41 Ibidem.

42 Ibidem. 
polityczne i program FvD, podkreślając, że głównym celem jego i partii jest zmniejszenie liczby imigrantów przybywających do Niderlandów.

Ciekawe, że Baudet wspiera działalność muzułmańskiej aktywistki Shirin Musy ${ }^{43}$, która walczy o równe prawa dla muzułmańskich kobiet. Poprzez tę wiadomość Baudet tworzy obraz siebie jako osoby integrującej i akceptującej mniejszości, zwolennika wolności i równości. Tweety swoje Baudet adresuje do tych, którzy wierza, że islam jako wyznanie jest opresyjny, ale go nie odrzuca. Nie jest tak radykalny w swoim myśleniu o islamie, jak Geert Wilders, w czym obserwatorzy sceny politycznej widzą główna różnicę między tymi dwoma skrajnie prawicowymi politykami. Inna jego grupa docelowa składa się $z$ tych, którzy sa przeciwko islamowi oraz obcokrajowcom i homoseksualizmowi.

\section{TWÓRCZOŚĆ PISARSKA}

Thierry Baudet jest płodnym pisarzem. Ma na swoim koncie dziewięć książek. Najbardziej znana $\mathrm{z}$ nich zatytułowana jest Atak na państwo narodowe (nid. De Aanval op de Natiestaat, 11 wydań!) druga Ojkofobia. Strach przed samym soba (nid. Oikofobie. De angst voor het eigene, 2013) oraz Miłość warunkowa (Voorwaardelijke liefde, 2014).

W ksiażce Atak na państwa narodowe pisał on o tożsamości narodowej, europejskiej integracji i wielokulturowości. Główna jego teza jest to, że zjednoczenie Europy i wielokulturowość osłabiły państwo narodowe.

Otwarty nacjonalizm, którego jestem zwolennikiem, nazywam wielokulturowym nacjonalizmem $-z$ jednej strony kontrastuje on $z$ wielokulturowościa, $z$ drugiej $z$ nietolerancyjnym, zamkniętym nacjonalizmem. Współpracę międzynarodowa na bazie demokratycznych państw narodowych nazywam suwerennym kosmopolityzmem - a to kontrastuje $z$ supranacjonalizmem $z$ jednej strony i odwrotnie, $z$ zamkniętym nacjonalizmem $z$ drugiej. Zarówno wielokulturowy nacjonalizm, jak i suwerenny kosmopolityzm głosza, że zglobalizowany współczesny świat wymaga otwartego umysłu, ale mimo to stawiają one państwo narodowe w sercu systemu politycznego ${ }^{44}$.

Twierdzi też, że demokratyczne państwo konstytucyjne może funkcjonować tylko w kontekście państwa narodowego. Takie ponadnarodowe struktury, jak Unia Europejska, Światowa Organizacja Handlu, Europejski Trybunał Praw Człowieka czy Międzynarodowy Trybunał

${ }^{43}$ Shirin Musa (ur. 1977) aktywistka polityczna pakistańskiego pochodzenia, założycielka, dyrektorka i siła napędową holenderskiej organizacji walczącej o prawa kobiet Femmes for Freedom.

${ }^{44}$ T. Baudet, De Aanval op de Natiestaat, Uitgeverij Bert Bakker, Amsterdam 2013, s. $11-12$. 
Karny, sa, zdaniem Baudeta, fundamentalnie sprzeczne $z$ demokracja. Państwo demokratyczne potrzebuje granic, aby utrzymać pewna spójność społeczna swoich obywateli i suwerenność w postaci Parlamentu, który jest przed nimi odpowiedzialny. A zatem: demokracja i rządy prawa sa ze soba ściśle powiąane i wymagaja społeczności politycznej, która jest osiadła na pewnym terytorium. Meindert Fennema, recenzent $z$ dziennika „De Volkskrant”, tak podsumowuje książkę:

Organizacje międzynarodowe i sądy, których decyzje nie podlegaja zatwierdzeniu przez suwerenne państwa, podważają suwerenność narodowa, a wraz z nia proces demokratyczny oraz zasady praworządności; wszystkie formy wielokulturowości, które uruchamiają równoległe systemy prawne, stanowia naruszenie prawnej równości obywateli, a zatem zasady rządów prawa ${ }^{45}$.

Niestety, w książce pojawiło się określenie „polskie obozy zagłady” (nid. Poolse vernietiginskampen). Na sprawę zareagowała Reduta Dobrego Imienia, która skierowała list do wydawnictwa, którego nakładem ukazała się ta książka ${ }^{46}$.

Druga książka Oikofobia. Strach przed samym soba dotyczy daleko sięgającej formy relatywizmu kulturowego ${ }^{47}$. Pojęcie to zrobiło w Polsce karierę dzięki Jarosławowi Kaczyńskiemu ${ }^{48}$. W debacie publicznej w Niderlandach po raz pierwszy posłużył się nim Baudet, który nie tylko odrzuca wielokulturowość, otwarte granice, sztukę współczesną (nie jej stronę estetyczna, ale konceptualna) oraz integrację europejska. Definiował on ojkofobię jako „chorobliwe odrzucanie bezpieczeństwa”. W jednym ze swoich artykułów porównał on Niderlandy z domem, którego mieszkańcy przyjmuja gości, a ci go następnie przejmuja $^{49}$. Tak podsumował tę książkę Jędrzej Winiecki:

Pożyczył od Scrutona ${ }^{50}$ - i machnał o tym książkę [...]. Krytycy zarzucają mu jednak, że pod pseudointelektualizmem, będącym mieszanką psychoanalizy

${ }^{45}$ https://www.volkskrant.nl/cultuur-media/aanval-op-de-natiestaat bde958e4/? referer=https $\% 3 \mathrm{~A} \% 2 \mathrm{~F} \% 2 \mathrm{Fwww}$.google.com\%2F [dostęp: 6 marca 2019].

46 https://niezalezna.pl/221802-w-ksiazce-klamstwo-o-polskich-obozach-stoi-za-tym -liczacy-sie-polityk-z-holandii [dostęp: 6 marca 2019].

${ }_{47}$ Ojkofobia, także oikofobia $\mathrm{z}$ j, greckiego, termin zdefiniowany w kontekście politycznym oznacza odrzucenie, brak akceptacji rodzimej kultury i apologię innych systemów wartości.

48 Lider PiS Jarosław Kaczyński podczas konwencji regionalnej w Olsztynie 24 września 2018, za: https://www.salon24.pl/u/salonowcy/897546,oikofobia-rzecz-o-ryzykownej-filozofii-prezesahttps:// natemat.pl/249829,reforma-sadownictwa-czym-jest-oikofobia [dostęp: 6 marca 2019].

49 Tegen oikofobie, de angst voor het eigene van hoogopgeleide Europeanen, NRC.nl, 7 września 2013, https://www.nrc.nl/nieuws/2013/09/07/tegen-oikofobie-de-angst-voorhet-eigene-van-hoogopgeleide-1288591-a1304196 [dostęp: 6 marca 2019].

50 Roger Scruton, wybitny angielski filozof, profesor Uniwersytetu Bostońskiego, twórca pojęcia ojkofobia. 
Zygmunta Freuda ze Zmierzchem Zachodu Oswalda Spenglera, przemyca treści ukryte i zwyczajnie niebezpieczne. Brak szacunku Baudeta dla współczesnej sztuki przypominać ma nazistowski stosunek do sztuki zdegenerowanej albo roli przypisywanej sztuce przez stalinizm i maoizm ${ }^{51}$.

W dniu 10 grudnia 2018 roku w Marrakeszu w Maroku 164 państwa członkowskie ONZ przyjęła niewiążący pakt w sprawie migracji Pakt GCM (Global Compact for Safe, Orderly and Regular Migration) ${ }^{52}$. Dokument został przyjęty przez aklamację, ale $z$ podpisania paktu wycofało się wiele państw, m.in. Polska. $Z$ powodu sporu o pakt rozpadła się w Belgii koalicja rządząca i prawicowa partia NVA, która przeszła do opozycji, pozostawiając władzę mniejszościowemu rządowi premiera Charlesa Michela. Akcja petycyjna Baudeta pod hasłem „Stop Marrakesz" nie powiodła się ${ }^{53}$. Królestwo Niderlandów jest jednym $z$ jego sygnatariuszy. Według Thierry'ego Baudeta, pakt ten jest narzędziem dla prawników zajmujacych się azylem, aby „bez końca” prowadzić spór $z$ państwem. Baudet $\mathrm{w}$ wywiadzie dla radia NPO1 mówił, że pakt ten $\mathrm{w}$ zasadzie promuje legalna imigrację i nazwał go otwartym zaproszeniem imigrantów do Niderlandów („Mówi się do Afryki: chodźcie tutaj. Jest to wyraźnie zawarte w tym pakcie") ${ }^{54}$.

\section{TRZECIA DROGA - MARK RUTTE I DOBRY POPULIZM}

Deklaracja premiera Marka Rutte, który po wyborach parlamentarnych w marcu 2017 roku z triumfem oświadczył, że „dobry populizm” pokonał „zły populizm”, zrobiło w Europie medialną karierę. Warto w tym miejscu przypomnieć, że populizm ma dobre i złe strony, mówił już o tym były lider CDA i były premier Ruud Lubbers ${ }^{55}$ we wrześniu 2011 roku na wykładzie w Groningen. Liczenie się $z$ opinia zwykłego człowieka to właśnie ta dobra forma populizmu, choć może on prowadzić do myślenia krótkoterminowego. Premier Rutte twórczo rozwinął tę myśl. Oświadczył on, że najlepszym sposobem na pokonanie

\footnotetext{
51 J. Winiecki, Holandia: Thierry Baudet - czarujacy populista...

52 https://www.tvp.info/40357330/oenzetowski-pakt-w-sprawie-migracji-przyjety-na -konferencji-w-marrakeszu [dostęp: 6 marca 2019].

53 https://forumvoordemocratie.nl/petities/stop-marrakesh [dostęp: 6 III 2019].

54 https://wnl.tv/2018/12/03/thierry-baudet-fvd-marrakesh-pact/ [dostęp: 6 marca 2019].

${ }_{55}$ https://www.cda.nl/drenthe/emmen/actueel/nieuws/lubbers-populisme-zowelgoed-als-slecht/ [dostęp: 6 marca 2019].
} 
populistycznej radykalnej prawicy jest kooptacja umiarkowanej wersji ich programu, $z$ wyłączeniem współpracy z nimi. Mark Rutte, Jesse Klaver ${ }^{56}$ i Alexander Pechtold ${ }^{57}$ ogłosili, że „zły populizm” nie zdobył przyczółku na ziemi niderlandzkiej. $Z$ tezą tą nie zgadza się Mark van Ostaijen. Populizm nie tylko nie zniknal, ani nie został zatrzymany. Wręcz przeciwnie, populizm stał się powszechnie akceptowaną forma głoszenia poglądów politycznych. Dzięki temu Geert Wilders ma obecnie większy wpływ na politykę rządu Marka Ruttego, niż sugeruje to liczba uzyskanych przez tego pierwszego mandatów. „Dobry” lub „zły” populizm może istnieć jedynie $z$ łaski „właściwego” lub „dobrego” populizmu $^{58}$. Ostrzegając przed złym populizmem i twierdząc, że Niderlandy powtrzymały jego ekspansję, Mark Rutte dał jednocześnie sygnał, że Niderlandy „przywitały się właśnie $z$ właściwym populizmem”, w wersji premiera. Jak pisał Mark van Ostaijen:

Od marginesu do głównego nurtu. Populizm jest sercem naszej demokracji. [...] uważam, że „populizm nie stracił swojej funkcji”, ale zyskał na znaczeniu ${ }^{59}$.

W czasie trzydniowej Konferencja Bezpieczeństwa Monachium w lutym 2018 roku Mark Rutte mówił tak:

Populizm wcale nie jest zly, trzeba słuchać ludzi i ich trosk - w przeciwnym razie jesteś arogancki. Istnieje zły populizm, który nie oferuje poważnych rozwiązań i chce jedynie sprowokować ${ }^{60}$.

Co dalej z rządami Marka Rute? Peter van der Heiden uważa, że zwiększy się wpływ Geerta Wildersa na jego rząd. W każdym razie populizm będzie mocno słyszany $\mathrm{w}$ gabinecie Ruttego, ponieważ VVD i CDA stanowić będa jego rdzeñ ${ }^{61}$. Choć, jak uważa premier, reprezen-

\footnotetext{
56 Jesse Feras Klaver (ur. 1986), niderlandzki polityk, poseł do Drugiej Izby Parlamentu, od 2015 lider Zielonej Lewicy (nid. GroenLinks).

57 Alexander Pechtold (ur.1965), niderlandzki polityk, od 2006 do 2018 lider partii Demokraci 66 (nid. D66).

58 Zob. na ten temat: C. Mudde, Why, good populism' is the wrong strategy to fight, bad populism', https://www.theguardian.com/world/commentisfree/2019/jan/03/good-populism-wrong-strategy-fight-bad-populism [dostęp: 6 marca 2019].

59 M. van Ostaijen, Het Goede Populisme, „Binnenlands Bestuur”, 3 kwietnia 2017, https://www.binnenlandsbestuur.nl/populisme [dostęp: 6 marca 2019].

${ }^{60}$ B. Savelberg, Premier Rutte: populisme is goed, „De Telegraaff”, 17 lutego 2018, https://www.telegraaf.nl/nieuws / 1685925/premier-rutte-populisme-is-goed?utm_source=google\&utm_medium=organic [dostęp: 6 marca 2019].

61 Po wyborach 15 marca 2017 powstał rząd, na który składa się koalicja Partii Ludowej na rzecz Wolności i Demokracji (VVD), Apelu Chrześcijańsko-Demokratycznego (CDA), Demokratów 66 (D66) i Unii Chrześcijańskiej (CU).
} 
tują oni dobry populizm, ale ten "dobry” populizm powstał z obawy przed „złym” populizmem. Obawa, że populizm PVV i FvD spowoduje zepchnięcie CDA i VVD na tę ścieżkę populistyczna, a nie zmusi do powrotu do własnych zasad, wpływ Wildersa na politykę dotychczasowej koalicji będzie wyraźnie większy. Obecnie tylko partia Demokraci 66 zdecydowanie sprzeciwiała się populistycznej tendencji. Peter van der Heiden watpi czy wytrwa ona w koalicji z VVD i CDA. „Przewiduję, że demokraci będą mieli duży dyskomfort, jeśli Rutte, czując na plecach goracy oddech Wildersa, nadal będzie uprawiał politykę populistyczna" ${ }^{\prime 2}$.

Analizy publikacji na temat populizmu w Europie po 2015 roku prowadza do wniosku, że ocena tego zjawiska wymaga przewartościowana siatki pojęciowej używanej do jego analizowania. Zwraca na to uwage m.in. Jan Pakulski, pisząc, że sam termin populizm współczesnie stosowany jest głównie w odniesieniu do kontestacyjnych ruchów społeczno-politycznych, zarówno „prawicowych” jak i „lewicowych”. Większość masowych ruchów populistycznych w XXI wieku ma charakter masowej kontestacji zarówno władzy, jak i ukształtowanego przez nia porządku społeczno-politycznego. Ruchy takie sa „przeciw”, raczej niż „za" ${ }^{\prime 3}$. Autor proponuje własną perspektywę analityczna (typy idealne) oraz teoretyczną opcję Weberowska, która „otwiera drogę do płodnej poznawczo analizy współczesnych ruchów populistycznych, szczególnie w ich aspekcie dynamicznym i historyczno-porównawczym" ${ }^{4}$. Zgadzając się $z$ kontestacyjną natura populizmu („za lub przeciw") wobec demokracji liberalnej, gdzie umieścić zatem populizm w obronie tejże demokracji? To pytanie pozostanie otwarte, bowiem nadchodzace lata zapowiadaja trudny proces „kohabitacji” państw europejskich $\mathrm{z}$ populizmem, jak to pokazuje analizowany przykład Królestwa Niderlandów.

\section{POST SCRIPTUM}

W dniu 20 marca 2019 roku w Niderlandach odbyły się krajowe wybory do Stanów Prowincjonalnych. Forum na rzecz Demokracji w wyborach tych wzięło udział po raz pierwszy i odniosło spektaku-

62 P. van der Heiden, Peter praat politiek (9): wat wil die kiezer nou? Peter praat politiek (9): wat wil die kiezer nou? Vox, https://www.voxweb.nl/nieuws/wil-kiezer-nou [dostęp: 6 marca 2019].

${ }^{63}$ J. Pakulski, Ruchy populistyczne i degeneracja elit przywódczych - analiza weberowska, „Zoon Politikon” 2016, nr 7, s. 21.

${ }^{64}$ Ibidem, s. 64 i n. 
larne zwycięstwo w co najmniej osiemdziesięciu gminach. Są to często społeczności zamieszkujące wokół dużych miast, ale także duże miasta, jak Rotterdam, Almere, Tilburg, Enschede, Lelystad i Hengelo. To miasta, w których w wyborach z 2015 roku zwycięstwo odnosily partie VVD premiera Ruttego i PVV Geerta Wildersa ${ }^{65}$. Wyniki wyborów wskazuja, że FvD stała się druga siła polityczną w Pierwszej Izbie Parlamentu (Senacie) po rządzacej VVD ${ }^{66}$.

65 Sa to pierwsze wyniki ogłoszone przez prasę 21 marca, https://www.trouw.nl/ home/bekijk-hier-de-uitslagen-van-de-provinciale-statenverkiezingen-2019 a1ac6c0b/

${ }^{66}$ Wybory $w$ Holandii: Sukces skrajnej prawicy. Koalicja rzadowa straci większość $w$ Senacie, https://www.rp.pl/Polityka/190329873-Wybory-w-Holandii-Sukces-skrajnejprawicy-Koalicja-rzadowa-straci-wiekszosc-w-senacie.html 